\title{
Does risk perception affect the way we practice ophthalmology? About the COVID-19 pandemic
}

\section{¿La percepción del riesgo afecta la forma en que practicamos la oftalmología? A propósito de la pandemia de COVID-19}

\author{
Juan P. Olivares-de Emparan* \\ Asociación para Evitar la Ceguera en México, Mexico City, Mexico
}

The outbreak of the coronavirus disease 2019 (COVID-19), caused by the severe acute respiratory syndrome coronavirus type-2 (SARS CoV-2), was identified in the first days of this year in Wuhan, China. It was declared a pandemic in March 20201. When finalizing this article (September 7, 2020), the recorded number of deaths amounted to 891,308 in the world, with 67,781 registered in Mexico, according to official figures ${ }^{2}$.

In 2003, the severe acute respiratory syndrome (SARS) pandemic significantly affected health professionals, representing $21.1 \%$ of cases $(1,076 / 8,096)^{3}$. Differences in the number of reported cases in each country, testing rates, performance of information systems, and the rapid increase in the number of infections make it difficult to adequately estimate the prevalence of SARS-CoV-2 among healthcare personnel ${ }^{4}$. Ing, et al. carried out a literature review regarding deaths reported among medical personnel as of April 25, and found a total of 254 deaths, of which 7 (4\%) corresponded to ophthalmologists ${ }^{5}$. These authors found no difference in the risk of ophthalmologists compared to other specialties ${ }^{5}$; however, the proximity to the patient during clinical and surgical activities represents a risk in the practice of the specialty ${ }^{6}$.

Additionally, there is a suspicion of virus excretion through tears or conjunctiva ${ }^{7}$. In a systematic review of the literature, in which the information published until April 21 regarding COVID-19 and ophthalmology was classified, we observe that the levels of evidence to support this theory are low and there are still questions about the risk of transmission through tears or conjunctival secretions. Likewise, the evidence related to the frequency and characteristics of the ocular manifestations of COVID-19 is still scarce, and more information is required to understand in depth the ocular effects of the virus ${ }^{8}$.

Two publications in this issue of the Revista Mexicana de Oftalmología are dedicated to topics related to COVID-19; both are based on surveys that collect information regarding the perception of ophthalmologists with respect to the disease and, therefore, the way in which we, as doctors, face the new reality of the practice of our specialty. López-Ulloa, et al. conducted a survey about the impact of the pandemic on ophthalmologists in Mexico. A total of 241 (66.6\%) participants mentioned that ophthalmologists had a higher risk of contagion compared to other medical specialties; 103 (28.5\%) believed the risk was similar, and 18 (4.9\%) believed it was lower. The participants with more than 30 years of practice were more likely to believe that the risk was higher, while younger ophthalmologists believed that the risk was similar to other specialties (JA López-Ulloa, personal communication, July 1, 2020).

Correspondence:

*Juan P. Olivares-de Emparan

Vicente García Torres 46,

Col. San Lucas Coyoacán

Date of reception: 09-07-2020

Date of acceptance: 10-07-2020

E-mail: olivares.juanpablo@gmail.com

2604-1731/O 2020 Sociedad Mexicana de Oftalmologí Published by Permanyer. This is an (http://creativecommons.org/licenses/by-nc-nd/4.0/).
Available online: 09-11-2020 Rev Mex Oftalmol (Eng). 2020;94(6):221-222

www.rmo.com.mx

Published by Permanyer. This is an open access article under the CC BY-NC-ND license 
The survey by Mier-Bolio, et al. collects data on the prevalence of anxiety in ophthalmologists at a reference center in Mexico City using two different scales. The observed prevalence was of $48 \%$ and $83 \%$, according to the measurement instrument, and most of the cases were classified as mild ${ }^{9}$.

Risk perception is a social phenomenon built from previous experiences and it is difficult to predict it with certainty. Qualitative studies among healthcare professionals have associated it with lower response rates during health emergencies due to other pathogens ${ }^{10,11}$. Gee, et al. conducted in-depth interviews with healthcare personnel during the Ebola outbreak in Africa in 2014-2016; factors associated with higher risk perception were societal and familiar perceived risk, information in the media and infections among colleagues. On the other hand, knowledge and trust in institutions mitigate this perception ${ }^{9}$. Balicer, et al. found that up to $50 \%$ of the healthcare personnel could absent from work during an influenza health crisis in Maryland, USA $^{11}$.

The impact secondary to risk perception in health professionals and their response to crisis situations are factors that affect the health system and, therefore, may increase the burden of diseases in society. Control policies in our institutions should be aimed at increasing self-determination, knowledge, and certainty among eye healthcare professionals in a way that such perception causes the least damage to the visual health of our population.

\section{References}

1. Wu D, Wu T, Liu Q, Yang, Z The SARS-CoV-2 outbreak: what we know. Int J Infect Dis. 2020;94:44-8.

2. Department of Civil and Systems Engineering - Johns Hopkins University. COVID-19 Dashboard. COVID-19 Dashboard by the CSSE at Johns Hopkins University. 2020. Disponible en: https://gisanddata.maps.arcgis. com/apps/opsdashboard/index.html\#/bda 7594740 fd40299423467b48e9ecf6.

3. World Health Organization. Summary of probable SARS cases with onset of illness from 1 November 2002 to 31 July 2003. WHO; 2004. Disponible en: https://www.who.int/csr/sars/country/table2004_04_21/en/

4. Lahner E, Dilaghi E, Prestigiacomo C, Alessio G, Marcellini L, Simmaco M, et al. Prevalence of Sars-Cov-2 Infection in Health Workers (HWs) and Diagnostic Test Performance : The Experience of a Teaching Hospital in Central Italy. Int J Environ Res Public Health. 2020;17(12):4417.

5. Ing EB, Xu QA, Salimi A, Torun N. Physician deaths from coronavirus (COVID-19) disease. Occupational Medicine. 2020;70(5):370-4.

6. American Academy of Ophthalmology. Alert : Important coronavirus updates for ophthalmologists. 2020. Disponible en: https://www.aao.org/ headline/alert-important-coronavirus-context.

7. Lu CW, Liu XF, Jia ZF. 2019-nCoV transmission through the ocular surface must not be ignored. Lancet. 2020;395:e39.

8. Olivares-de Emparan JP, Sardi-Correa C, López-Ulloa JA, Viteri-Soria J, Penniecook JA, Jimenez-Román J, et al. COVID-19 and the eye: how much do we really know? A best evidence review. Arq Bras Oftalmol. 2020;83:250-61.

9. Mier-Bolio JR, Arroyo-González JM, Baques-Guillen E, et al. COVID-19 y ansiedad en oftalmólogos. Rev Mex Oftalmol. 2020;94(6): XXXXXX

10. Gee S, Skovdal M. The role of risk perception in willingness to respond to the 2014-2016 West African Ebola outbreak: a qualitative study of international health care workers. Glob Health Res Policy. 2017;2:1-10.

11. Balicer RD, Omer SB, Barnett DJ, Everly GS. Local public health workers' perceptions toward responding to an influenza pandemic. BMC Public Health. 2006;6:1-8. 